\title{
A Study of Prevalence of Taenia Infestation and Associated Risk Factors Among the School Children of Dharan
}

\author{
Sah RB, ${ }^{1}$ Pokharel PK, ${ }^{1}$ Paudel IS, ${ }^{1}$ Acharya $A,{ }^{2}$ Jha $N,{ }^{1}$ Bhattarai $S^{1}$
}

${ }^{1}$ School of Public Health and Community Medicine, BPKIHS, Dharan, Nepal

${ }^{2}$ Department of Microbiology, Chitwan Medical College, Bharatpur, Nepal

\section{Corresponding Author}

Ram Bilakshan Sah

School of Public Health and Community Medicine BPKIHS, Dharan, Nepal

Email: bilaksah@yahoo.com

Citation

Sah RB, Pokharel PK, Paudel IS, Acharya A, Jha $\mathrm{N}$, Bhattarai S. A Study of Prevalence of Taenia Infestation and Associated Risk Factors Among the School Children of Dharan. Kathmandu Univ Med J 2012;39(3):14-17.

\begin{abstract}
Background

Taenia prevalence has remained high among certain ethnic groups and occupational diseases in Nepal. Taenia saginata and Taenia solium species are worldwide in distribution. Infection is found most often in rural areas of developing countries with poor hygiene and living in close contact with pigs and eating undercooked pork meats. This allows the tapeworm infection to be completed and its cycle to continue.
\end{abstract}

\section{Objectives}

To measure the prevalence of taenia infestation and to identify risk factors associated with taenia infestation among the school children of Dharan.

\section{Methods}

A cross sectional study was conducted among 935 Government and private school going children of Grade VI, VII, and VIII of Dharan during 2007 to 2008. Stratified random sampling method was applied to choose the schools and the study subjects. The prevalence was calculated, Chi-square test was used to measure the association of risk factors and taenia infestation.

\section{Results}

Taenia species was found to be high (5.5\%) among the school children of Dharan. Infection rate of taenia among the male children (6.0\%) was slightly higher than female (4.8\%). There were no cases of taenia infestation found among children washing hands with soap. Regarding meat consumption in the non-vegetarian group, taenia infestation was found higher (6.5\%) among pork eating than nonpork eating $(4.7 \%)$. No significant relationship was traced among the factors in the causation of taenia infestation although slight indications present.

\section{Conclusion}

Taenia species was found very high among the school children of Dharan. No such association was found with the risk factors.

\section{KEY WORDS}

Prevalence, risk factors, taenia infestation, school children, Dharan

\section{INTRODUCTION}

Taenia solium infection is worldwide and endemic in humans who eat raw or inadequately cooked pork. The disease in humans and pigs is an ancient parasitic disease rooted in developing countries and emerging as a major health problem of global dimensions. ${ }^{1}$ Infection is common in low socio-economic and poor sanitary areas of central and southern Mexico, and central and southern America. The infection is also present in India, Pakistan, North China, Thailand, and Nepal. ${ }^{2}$
The incidence of taeniasis is common in developing countries, including Nepal, where people have a habit of defecating in open fields. The close relationship between humans and pigs in some rural areas, where the pigs live practically in the houses of the owners and feed on kitchen waste and excreta, explains the high prevalence of Taenia solium infections in several developing countries, including Nepal. $^{3}$ 
The symptomatology of neurocysticercosis varies with the number of cysticerci and with their location in the central nervous system. Experimental infection of pigs with high doses of $T$. solium eggs can produce fever and stiffness of the muscles. Death may occur as a result of degenerative myocarditis. In general, the normal economic lifespan of the pig is too short for symptoms to become apparent. ${ }^{4}$

In Nepal, very few research works has been carried out, and very few authentic research articles have been published. The published and unpublished data indicate that the disease has been established in the country, and is developing into a serious public health problem. This study is designed to measure the prevalence of taenia infestation and to identify risk factors associated with taenia infestation.

\section{METHODS}

A cross-sectional study was conducted during August 2007 to august 2008 in Grade 6,7,8 in Government and Private Schools of Dharan. Stratified random sampling method was applied to choose the schools and the study subjects. Out of total 90 schools in Dharan, 22 were government (25\%) and 68 were private schools (75\%).To represent the children for $30 \%$ taenia infestation (Joshi DD et al) sample size calculated was $935 .{ }^{3}$ Out of 935, 25 percent (229) were taken from Government schools and 75 percent (705) were taken from private schools on the basis of probability proportionate to sample size. Study subjects were enrolled till the required sample size was full filled.

Variables included in the study are gender, religion, ethnicity, personal hygiene (hand washing after defecation, bath, skin, nail, and clothes examination), food habit and meat consumption.

Semi-structured questionnaire was administered to the study subjects and Microscopic Examination of Stool was done. In each visit more than 20 students were enrolled \& same number of plastic bottles was given for stool collection and collected next day morning. Microscopic examination of stool was done by preparing slide using Normal Saline and Lugol's lodine to observe the ova of Taenia solium, Taenia saginata and other worms. ${ }^{5}$

The prevalence was calculated, Chi-square test was used to measure the association of risk factors and taenia infestation. The confidence level was set at $5 \%$ in which probability of occurrence by chance will be significant if $\mathrm{P}<$ 0.05 .

\section{RESULTS}

Taenia species was seen high (5.5\%) among the school children of Dharan. Infection rate of taenia among the male children was slightly higher than female. Similarly, taenia infestation among Hindu was higher than others (Buddhist, Christian and Muslims) (table.1). The respondents from
Table 1. Distribution of study population by Gender, religion, and ethnicity with taenia infestation.

\begin{tabular}{|llll|}
\hline Characteristics & Taenia positive & Total number & P- Value \\
\hline Gender & & & \\
\hline Male & $30(6.0 \%)$ & 498 & 0.413 \\
\hline Female & $21(4.8 \%)$ & 437 & \\
\hline Religions & & & 0.589 \\
\hline Hindu & $47(5.6 \%)$ & 841 & \\
\hline Others & $4(4.3 \%)$ & 94 & 0.794 \\
\hline Ethnicity & & & \\
\hline Kirati & $21(5.5 \%)$ & 382 & \\
\hline Janajati & $17(6.1 \%)$ & 280 & \\
\hline Others & $13(4.8 \%)$ & 273 & 935 \\
\hline Total & $51(5.5 \%)$ & & \\
\hline
\end{tabular}

Table 2. Personal hygiene and taenia infestation.

\begin{tabular}{|c|c|c|c|}
\hline Characteristics & Taenia Positive & Total number & P-Value \\
\hline \multicolumn{4}{|c|}{ Hand washing after defecation } \\
\hline Water & $51(5.5 \%)$ & 932 & \multirow[t]{2}{*}{0.677} \\
\hline Soap & $0(0.0 \%)$ & 3 & \\
\hline \multicolumn{4}{|l|}{ Bath } \\
\hline Regular & $43(5.1 \%)$ & 835 & \multirow[t]{2}{*}{0.236} \\
\hline Irregular & $8(8.0 \%)$ & 100 & \\
\hline \multicolumn{4}{|l|}{ Skin } \\
\hline Clean & $30(5.4 \%)$ & 559 & \multirow[t]{2}{*}{0.885} \\
\hline Non clean & $21(5.6 \%)$ & 376 & \\
\hline \multicolumn{4}{|l|}{ Nail } \\
\hline Clean & $25(5.5 \%)$ & 453 & \multirow[t]{2}{*}{0.933} \\
\hline Not-clean & $23(5.5 \%)$ & 482 & \\
\hline \multicolumn{4}{|l|}{ Clothes } \\
\hline Clean & $28(5.5 \%)$ & 513 & \multirow[t]{3}{*}{0.996} \\
\hline Not-clean & $23(5.5 \%)$ & 422 & \\
\hline Total & $51(5.5 \%)$ & 935 & \\
\hline
\end{tabular}

Janajati (6.1\%) were found with higher taenia infestation followed by Kirati (5.5\%), and very less proportion of others (Brahmin, Chhetri, Dalit and Terai caste $4.8 \%$ ) but the difference is not significant.

Table no. 2 shows no significant relationship found in the hand washing habit after defecation and Taenia infestation. There were no cases of Taenia infestation found among children washing hands with soap. All the Taenia infestations were found among child hand washing with water only.The taenia infestation among children with irregular bath was higher than regular bath. Almost similar trend was found in skin cleanliness, nail cleanliness and cloth cleanliness

In food habit, no significant relationship was found with taenia infestation. Taenia infestation was found slightly higher among non-vegetarian children than vegetarian. Regarding meat consumption in the non-vegetarian group, taenia infestation was found higher among pork eating than non-pork eating. 
Table 3. Food habit and taenia infestation.

\begin{tabular}{|llll|}
\hline Characteristics & Taenia Positive & Total number & P-Value \\
\hline Food habit & & & \\
\hline Vegetarian & $5(4.7 \%)$ & 107 & 0.705 \\
\hline Non-vegetarian & $46(5.6 \%)$ & 828 & \\
\hline Pork & $25(6.5 \%)$ & 382 & 0.250 \\
\hline Non-Pork & $21(4.7 \%)$ & 446 & \\
\hline Total & $51(5.5 \%)$ & 935 & \\
\hline
\end{tabular}

\section{DISCUSSION}

The animals that are used for meat in Nepal are chickens, goats, pigs, buffalo and sheep. Meat provides protein, vitamins, minerals, and fat necessary for good health and growth. Meat protein contains essential amino acids (protein elements) needed to build and maintain body tissues. $^{3}$

In this study, Taenia species was seen high (5.5\%) among the school children of Dharan. But in west Cameroon, human taeniasis $(0.13 \%)$ was found which is less as compared to our study. ${ }^{6}$

Taenia was observed slightly higher (6\%) among male but not significantly higher than female (4.8\%). A study conducted in Ethiopia showed (13.4\%) fecal samples were confirmed to be taeniasis by direct smears and copro-ELISA. T. Saginata cases was significantly higher in males (82.1\%) than in females (17.9\%), respectively. ${ }^{7}$

Similar type of study conducted in Ethiopia showed that the prevalence of Taenia varies from (17.9\% to $82 \%$ ) which is very high as compared to our study. The study showed that T. Saginata cases was $(82.1 \%)$ in males, and $(17.9 \%)$ in female, respectively. In ketewes village (Indonesia), the number of families consuming raw beef (lawer) increased from (19.2\%) in 2002 to (32.4\%) in 2004. Male was found higher than female in additional village community because adult male groups often enjoy raw beef (lawer) using spirit. ${ }^{7}$

In our study, Taenia infestation among Hindu (5.6\%) was higher than others (Buddhist, Christian and Muslims 4.3\%) but the difference is not significant. Taenia solium is rare in Indonesia as a whole because of the Islamic taboo on eating pork however, in a number of areas (eg. Papuaand Timor) it is a public health problem, as it has previously been in Bali. ${ }^{8,9}$

The ethnic group was divided into three categories as suggested Kirati, Janajati, and others (Brahmin, Chhetri, Dalit and Terai caste). The respondents from Janajati (6.1\%) were found higher taenia infestation followed by Kirati (5.5\%) and very less proportion of others $4.8 \%$ (Brahmin, Chhetri, Dalit and Terai caste) but the difference is not significant. Similar kind of study done by Joshi DD et al found Taeniasis infections related to the ethnic groups surveyed and their food habits, literacy rates, and hygiene and sanitation. The prevalence of taeniasis among the ethnic groups surveyed, i.e. Magars, Sarkies, Darai and Bote, was found to be $50 \%, 28 \%, 10 \%$, and $30 \%$, respectively. Magar people are known for rearing pigs and eating much more pork than other ethnic groups, while the Sarkies are the poorest of the ethnic groups and are known to consume rotting cattle carcasses. ${ }^{3}$

Personal hygiene is the variable which is related to the behavior of various ethnic groups. There are certain religious taboos regarding meat consumption, for example, Hindus are not supposed to eat beef; many Jews and Muslims do not eat pork. Depending upon the availability of the animals and cultural habits, meat consumption is different in different countries and various religious communities. In Dharan, the majority of the population belong to Rai, Limbu, and Magar ethnic groups, and due to their socio-economic and cultural conditions, consumption of pork is very high. ${ }^{3}$

Our study showed Taneia infestation slightly higher among Janajati followed by Kirati who use pork meat frequently but the difference was not significant. A study conducted by Rai et al showed that parasite positive rate was higher in Dalits (known as low socio-economic group of Nepal) than other ethnic groups but it was not statistically significant. ${ }^{10}$

The distribution of Taenia species was (50\%) among Magars. It has been documented that pigs raised on private farms have a greater risk of ingesting human feces, due to the poor sanitary measures adopted. Pigs on private farms are generally slaughtered without veterinary inspection. In all environments where animal cysticercosis is prevalent, human taeniasis is very likely. Stool test results in Bote and Darai communities showed the prevalence rate of intestinal parasites among the Bote ethnic group was (76\%), which was greater than the Darai ethnic group (50\%). This revealed their poor education, knowledge, poor hygiene and sanitation, low socio-economic condition, and conservative lifestyle. ${ }^{3}$

The main limitation of this study is the risk factors of Taenia infestation can not determined because Grade 6, 7 and 8 may not give the right information regarding kitchen and food habits and the information was based on respondents answer rather than direct observation.

The review of taeniasis and cysticercosis research in Nepal showed that parasitic infections have existed for many years, but recording them on the basis of research is still in its infancy. The available data on taeniasis, and human and porcine cysticercosis, indicated that the disease is very severe and developing into a serious public health problem.

\section{CONCLUSION}

It was concluded that Taenia species was found very high among the school children of Dharan. Even though there are slight indications of risk factors like hand washing after defecation, bath, personal hygiene, food habit, meat consumption etc determining the Taenia infestation but 
our study couldn't significantly associated with risk factors with Taenia infestation. So, further strong study probably a case control study can make picture clearer.

\section{ACKNOWLEDGEMENT}

We would like to extend our true and sincere thanks to School of Public Health and Community Medicine for

\section{REFERENCES}

1. Sciutto E, Fragoso G, Fleury A. Taenia solium disease in humans and pigs. Microbes Infect 2000; 2:1875-90.

2. Schantz PM, Annc C, Moore JL. Neurocysticercosis in an arthodox Jewish community in New York City. N Engl J Med 1992; 327:629- 95.

3. Joshi DD, Maharjan M, Johnsen MV, Willingham AL, Gaihr Y, Sharma M. Taeniasis/ Cysticercosis situation in Nepal. Southeast Asian Journal of Tropical Medicine and Public Health 2004; 35: 252-258.

4. Pedro N, Acha BS. Zoonoses and communicable diseases common to man and animals. Washington DC: PAN American Health Organization. 1980; 499-504.

5. Godkar PB, Godkar DP. Microscopic examination of stool specimen. Text book of Medical Laboratory Technology. 2nd edition, 2003, page 937-952.

6. Merid Y, Hegazy M, Mekete G, Teklemariam S. Intestinal helminthic infection among children at Lake Awassa Area, South Ethiopia. The Ethiopian Journal of Health Development 2001;1(15): 31-38. support, encouragement and approval of our research work. We are grateful to Nepal Health Research Council for providing grant for the research on July 30, 2008 and the constant support and encouragement during the study. Our gratitude and sincere thanks to all the participants of study from Schools of Dharan and teachers for their kind co-operation. We would also like to thank all other people who stood by us throughout the study period

7. Wandra T, Sutisna P, Dharmawan NS, Margono SS, Sudewi R, Suroso $\mathrm{T}$, Craig PS, Ito A. High prevalence of Taenia saginata taeniasis and status of Taenia solium cysticercosis in Bali, Indonesia 2002-2004. Transactions of the Royal Society of Tropical Medicine and hygiene 2006; 100: 346-353.

8. Ito A, Nakao M, Wandra T. Human taeniasis and cysticercosis in Asia. Lancet 2003; 362: 1918-1920.

9. Ito A, Wandra T, Yamasaki $H$, Nakao $M$, Saka $Y$, Nakaya $K$ et al. Cysticercosis / taeniasis in Asia and the pacific. Vector Borne Zoonotic Dis 2004; 4: 95-107.

10. Rai SK, Hirai K, Abe A et al. Intestinal parasitosis among school children in a rural hilly area of Dhading District, Nepal. Nepal Med Coll J 2002; 4: 54-8. 